\title{
Tabel Prediksi Moyers dan Sitepu terhadap Lebar Mesiodistal Gigi Permanen Pengganti pada Etnis Arab Yaman di Surabaya
}

\section{(Moyers and Sitepu's Table Prediction Compare to Permanent Teeth Mesiodistal Width of Yemeni Etnic in Surabaya)}

\author{
Firyal Baktir, Dwi Prijatmoko, Masniari Novita \\ Program Studi Pendidikan Dokter Gigi, Fakultas Kedokteran Gigi Universitas Jember \\ Jl. Kalimantan 37, Jember 68121 \\ firyallel@gmail.com
}

\begin{abstract}
There are several methods of analizing tooth size discrepancy in orthodontics include prediction methods for mixed dentition. Prediction method of Moyers and Sitepu most commonly used although both were obtained from 2 different races, Caucasian and Deutromelayu. Yemeni ethnic is one of the ethnic groups settled in Indonesia which descendants of the Caucasian race. The aim of the study was to observed the suitable prediction table for Yemeni ethnic. It was an observasional analitics study consist of 40 samples with cross sectional design. The results showed that slight difference for prediction of Moyers on the maxilla (1.02) and prediction of Sitepu on the mandibula (0.11). As conclusion, the most suitable predicition method for Yemeni ethnic is Moyers's method for maxila and sitepu's method for mandibula.
\end{abstract}

Key words: mesiodistal width permanen teeth, Moyers method, Sitepu method, Yemeni Etnic

\begin{abstract}
Abstrak
Analisa kebutuhan ruang dalam bidang orthodonti terdapat berbagai cara termasuk metode prediksi pada masa gigi geligi campuran. Metode prediksi Moyers dan Sitepu adalah metode yang sering digunakan walaupun didapatkan dari 2 ras yang berbeda yaitu ras Kaukasoid dan Deutromelayu. Etnis Arab Yaman adalah salah satu etnis yang menetap di Indonesia dan merupakan keturunan ras Kaukasoid. Penelitian ini bertujuan untuk mengamati tabel prediksi yang sesuai untuk etnis Arab Yaman. Jenis penelitian ini observasional analitik terdiri dari 40 sampel dengan pendekatan cross sectional. Hasil penelitian menunjukkan bahwa selisih yang lebih menunjukkan sedikit perbedaan adalah prediksi Moyers pada rahang atas $(1,02)$ dan prediksi Sitepu pada rahang bawah $(0,11)$. Dengan demikian, metode prediksi yang tepat untuk etnis Arab Yaman adalah metode Moyers untuk rahang atas dan metode Sitepu untuk rahang bawah.
\end{abstract}

Kata kunci: lebar mesiodistal gigi permanen pengganti, metode Moyers, metode Sitepu, etnis Arab Yaman. 


\section{Pendahuluan}

Pengukuran lengkung gigi yang tersedia dan pengukuran jumlah lebar mesiodistal gigi permanen pengganti dalam bidang ortodonti digunakan untuk menganalisis kebutuhan ruang. Beberapa metode untuk memprediksi jumlah lebar gigi permanen telah dikembangkan, diantaranya yang sering digunakan adalah penggunaan metode Moyers dan Sitepu. Persamaan Moyers menggunakan ras Kaukasoid sedangkan Sitepu menggunakan ras DeutroMelayu sehingga keakuratan prediksi lebar mesiodistal gigi akan akurat hanya bila digunakan pada populasi yang sama. Perbedaan pada tabel prediksi gigi pengganti pada kedua metode tersebut kemungkinan akan membuat hasil yang berbeda bila digunakan pada ras tertentu ${ }^{1}$

Ukuran lebar mesiodistal gigi bervariasi karena dipengaruhi oleh beberapa faktor, yang utama adalah genetik, ras dan jenis kelamin, dan lingkungan sehingga ukuran lebar mesiodistal dan panjang gigi antara ras satu dengan yang lainnya akan bisa berbeda ${ }^{2}$. Penelitian yang dilakukan oleh Fernandes, Sathler (2013) mengenai perbedaan lebar mesiodistal pada ras Kaukasoid, Afrika dan Jepang menunjukkan hasil bahwa ras Negroid memiliki jarak mesiodistal lebih lebar daripada Jepang dan Kaukasian.

Indonesia merupakan negara multietnis karena ditinggali oleh banyak etnis yang mempunyai ciri khas masing-masing salah satunya yaitu etnis Arab Yaman. Etnis Arab Yaman, yang merupakan kelompok ras Kaukasoid dan mempunyai karakeristik fisik yang berbeda dengan etnis Mongoloid dan Negroid, termasuk bentuk dan ukuran gigi. Oleh karena itu, kemungkinan terdapat perbedaan lebar mesiodistal pada etnis Arab Yaman dengan etnis lain. ${ }^{3}$ Dengan demikian, kemungkinan terdapat persamaan lebar mesiodistal gigi permanen pengganti etnis Arab Yaman dengan prediksi Moyers.

\section{Metode Penelitian}

Jenis penelitian ini adalah observasional analitik dengan pendekatan cross sectional. Penelitian ini dilaksanakan di SMP dan SMA AIIrsyad Surabaya. penelitian menggunakan 40 sampel. Kriteria sampel adalah keturunan etnis Arab Yaman dari ayah maupun ibu, berusia antara 13-18 tahun, gigi permanen pengganti telah erupsi sempurna, dan tidak mengalami karies, fraktur dan atrisi daerah mesiodistal serta bukan hasil tumpatan, tidak mengalami kelainan ukuran dan bentuk gigi, dan tidak sedang melakukan perawatan orthodonsia.

Dilakukan pencetakan rahang atas dan rahang bawah dengan menggunakan alginate kemudian dilakukan pengecoran menggunakan gips kuning tipe 3 pada gigi yang diukur dan gips biru tipe 2 pada keseluruhan model cetak. Model cetak yang didapatkan kemudian dilakukan pengukuran pengukuran menggunakan kaliper digital pada keempat gigi insisivus rahang bawah yang digunakan untuk memperoleh hasil prediksi gigi permanen pengganti berdasarkan tabel prediksi Moyers dan tabel prediksi Sitepu. Pengukuran juga dilakukan pada gigi kaninus, premolar pertama serta premolar kedua pada tiap rahang yang kemudian dijumlahkan untuk mengetahui jumlah gigi geligi permanen pengganti sebenarnya. Pengukuran dilakukan dengan cara meletakkan kedua ujung kaliper digital yang runcing dengan posisi tegak lurus pada titik kontak bagian proksimal permukaan yang paling lebar dan sejajar dengan oklusal atau vestibular pada model gigi kemudian hasil pengukuran dijumlahkan. Pengukuran ini dilakukan pada regio kanan-kiri rahang atas dan rahang bawah.

Data yang telah diperoleh kemudian dilakukan perhitungan dengan cara menghitung selisih antara rerata lebar mesiodistal gigi sebenarnya etnis Arab Yaman dengan rerata prediksi Moyers dan Sitepu.

\section{Hasil Penelitian}

Data pengukuran lebar mesiodistal gigi permanen pengganti etnis Arab Yaman yang dilakukan pada 40 sampel diperoleh lebar mesiodistal gigi pengganti rahang atas dan rahang bawah disajikan pada tabel 1

Tabel 1. Rata-rata lebar mesiodistal gigi insisivus rahang bawah serta gigi permanen pengganti rahang atas dan rahang bawah pada etnis Arab Yaman yang sebenarnya

\begin{tabular}{|c|c|c|}
\hline \multicolumn{3}{|c|}{ Lebar mesiodistal etnis Arab Yaman } \\
\hline Insisivus RB & 345 RA & 345 RB \\
\hline 22,64 & 21,28 & 21,16 \\
\hline
\end{tabular}

Data hasil penelitian juga diperoleh prediksi gigi permanen pengganti berdasarkan tabel Moyers dan Sitepu yang didapatkan dari jumlah lebar mesiodistal keempat insisivus rahang bawah disajikan pada tabel 2 . 
Tabel 2. Rata-rata lebar mesiodistal gigi insisivus rahang bawah dan prediksi gigi permanen pengganti berdasarkan tabel Moyers dan Sitepu

\begin{tabular}{|c|c|c|c|c|}
\hline \multirow{2}{*}{$\begin{array}{c}\text { Insisivus } \\
\text { RB }\end{array}$} & \multicolumn{2}{|c|}{ Sitepu } & \multicolumn{2}{c|}{ Moyers } \\
\cline { 2 - 5 } & $345 \mathrm{RA}$ & $345 \mathrm{RB}$ & $345 \mathrm{RA}$ & $345 \mathrm{RB}$ \\
\hline 22,64 & 22,60 & 21,27 & 22,30 & 21,92 \\
\hline
\end{tabular}

Data hasil penelitian kemudian dihitung untuk mengetahui selisih antara lebar mesiodistal gigi permanen pengganti sebenarnya etnis Arab Yaman dengan rerata lebar mesiodistal gigi permanen pengganti prediksi Moyers dan prediksi Sitepu untuk mengetahui seberapa jauh perbedaan.

Tabel 4.3 Selisih lebar mesiodistal sebenarnya etnis Arab Yaman dengan prediksi Moyers.

\begin{tabular}{ccc}
\hline & 345 RA & 345 RB \\
\hline Moyers & 22,30 & $\mathbf{2 1 , 9 2}$ \\
Sebenarnya & 21,28 & $\mathbf{2 1 , 1 6}$ \\
& & \\
\hline & $\mathbf{1 , 0 2}$ & $\mathbf{0 , 7 6}$ \\
\hline
\end{tabular}

Hasil perhitungan ini memperlihatkan bahwa selisih rerata rahang atas etnis Arab Yaman terhadap metode Moyers menunjukkan angka 1,02. Hal ini menunjukkan bahwa hasil selisih lebar mesiodistal gigi permanen pengganti dengan prediksi Moyers menunjukkan adanya perbedaan yang lebih besar pada rahang atas. Hasil perhitungan selisih rerata rahang bawah etnis Arab yaman menujukkan angka 0,76 yang menandakan adanya perbedaan yang sangat sedikit dengan metode prediksi Moyers.

Tabel 4.4 Selisih lebar mesiodistal sebenarnya etnis Arab Yaman dengan prediksi Sitepu.

\begin{tabular}{ccc}
\hline & 345 RA & 345RB \\
\hline Sitepu & 22,60 & 21,27 \\
Sebenarnya & 21,28 & 21,16 \\
\hline & $\mathbf{1 , 3 2}$ & $\mathbf{0 , 1 1}$ \\
\hline
\end{tabular}

Perhitungan juga diukur untuk mengetahui selisih antara lebar mesiodistal gigi permanen pengganti etnis Arab Yaman dengan prediksi Sitepu. Hasil perhitungan memperlihatkan bahwa selisih rerata rahang atas etnis Arab Yaman terhadap metode Sitepu menunjukkan angka 1,32. Hal ini menunjukkan bahwa hasil selisih lebar mesiodistal gigi permanen pengganti dengan prediksi Sitepu menunjukkan adanya perbedaan yang lebih besar pada rahang atas dibandingkan dengan prediksi Moyers yang menunjukkan angka selisih 1,02. Hasil perhitungan selisih rerata rahang bawah etnis Arab yaman menunjukkan angka 0,11 yang menandakan adanya perbedaan lebih kecil dengan metode prediksi Sitepu dibandingkan dengan selisih prediksi Moyers yang menunjukkan angka 0,76.

\section{Pembahasan}

Tingginya kebutuhan perawatan orthodonti harus diimbangi dengan peningkatan kualitas pelayanan oleh dokter gigi untuk keberhasilan perawatan. Keberhasilan perawatan ortodonsi terutama orthodonti lepasan atau cekat sangat bergantung pada perencanaan perawatan termasuk macam perawatan untuk menentukan dilakukan pencabutan gigi atau tidak. Penentuan macam perawatan diperoleh dari perhitungan diskrepansi pada model yaitu perbedaan antara tempat yang dibutuhkan dengan tempat yang tersedia. Tempat yang tersedia didapatkan dari perhitungan langsung pada model sedangkan tempat yang dibutuhkan tidak selalu bisa dihitung langsung dari model apabila terdapat gigi geligi yang belum erupsi, untuk itu digunakan metode prediksi untuk mengukur tempat yang dibutuhkan 4,5 .

Tabel prediksi yang selama ini dihasilkan mempunyai manfaat klinis yang terbatas karena tabel prediksi untuk ukuran gigi geligi hanya tersedia untuk populasi tertentu sedangkan apabila digunakan untuk populasi yang lain akan mengurangi keakuratan dari prediksi tersebut ${ }^{6}$. Metode Moyers dan metode Sitepu merupakan metode prediksi yang biasa digunakan dalam mengukur tempat yang dibutuhkan di bidang orthodonti. Kedua metode ini juga menggunakan ras yang berbeda dalam perolehan hasil prediksinya. Data prediksi Moyers didapatkan dari ras Kaukasoid sedangkan metode prediksi Sitepu diperoleh dari Deutromelayu sehingga terdapat perbedaan perhitungan dalam tabel prediksi keduanya $^{7,8}$. 
Pengukuran langsung dilakukan pada model untuk mengukur lebar mesiodital gigi caninus, premolar pertama dan premolar kedua sehingga fase sampel yang digunakan adalah fase gigi geligi permanen. Hal ini tidak akan mempengaruhi hasil pengukuran karena ukuran gigi manusia relatif tetap dan tidak bertambah seiring usia ${ }^{9}$. Pengukuran langsung juga dilakukan pada keempat insisivus rahang bawah untuk memperoleh angka prediksi gigi caninus, premolar pertama, premolar kedua dari berdasarkan prediksi Moyers dan Sitepu ${ }^{10}$

Perbedaan ukuran gigi etnis Arab Yaman dengan etnis lain sangat mempengaruhi hasil penelitian. Hal ini sesuai dengan penelitian Huang et al (2012) ${ }^{11}$ yang menunjukkan bahwa adanya pola ukuran yang berbeda antar populasi dan ukuran variasi gigi yang berbeda ditentukan juga oleh genetik dan faktor lingkungan. Selain itu juga dipengaruhi oleh faktor jenis kelamin, etnik, dan ras. Ukuran gigi merupakan faktor yang penting dan mempengaruhi hasil dari prediksi dalam pengukuran diskrepansi ruang dalam bidang orthodonti termasuk ukuran gigi geligi etnis Arab Yaman yang tinggal di Indonesia. ${ }^{12,13}$.

Hasil penelitian menunjukkan metode yang sesuai untuk rahang atas adalah metode Moyers. Kecocokan dengan tabel prediksi Moyers pada rahang atas kemungkinan karena gen asal etnis Arab Yaman masih dominan sehingga tabel prediksi Moyers yang berasal dari ras Kaukasoid juga masih bisa digunakan. Faktor genetik memiliki peran yang cukup besar pada individu. Faktor keturunan atau faktor genetik mempunyai pengaruh yang terbesar dalam ukuran gigi setiap individu ${ }^{14}$.

Hasil penelitian juga menunjukkan metode yang sesuai untuk etnis Arab Yaman adalah Sitepu pada rahang bawah yang data prediksinya diperoleh dari ras Deutromelayu, hal ini berarti gigi geligi orang Arab Yaman yang tinggal di Indonesia memiliki ukuran gigi yang hampir sama dengan orang Indonesia. Hal tersebut karena etnis Arab Yaman di Indonesia berhasil melakukan pembauran dengan baik sehingga adaptasi terhadap lingkunganpun juga berjalan dengan baik. Adaptasi ini membuat orang Arab Yaman yang tinggal mengalami perubahan fisik seperti orang setempat sesuai dengan hasil penelitian. Proses modifikasi fisik tersebut terjadi karena etnis Arab Yaman telah menetap di Indonesia selama sekitar 300 tahun dan menetap secara berkelompok ${ }^{15}$. Etnis Arab Yaman masih terus menetap serta menghasilkan keturunan di Indonesia sehingga telah mempengaruhi ciri fisik dari populasi tersebut. Hal tersebut dapat terjadi karena orang Arab Yaman yang tinggal di Indonesia telah hidup selayaknya orang Indonesia, yaitu makan makanan Indonesia, hidup dan berkembang di iklim Indonesia sehingga hasil pengukuran yang lebih dominan terhadap metode Sitepu ${ }^{16}$.

Perubahan fisik etnis Arab Yaman menjadi seperti orang Deutro-Melayu disebabkan karena lingkungan hidup. Lingkungan adalah semua kondisi di dalam dan di luar organisme yang berpengaruh terhadap perilaku kita, perkembangan atau proses hidup kecuali gen. Lingkungan sendiri bisa mencakup iklim, gizi, suhu, geografis, maupun motivasi ${ }^{17}$. Lingkungan sebagai tempat hidup mempengaruhi frekuensi suatu sifat yang dapat diturunkan dalam populasi. Individu yang cocok dengan lingkungan tinggal akan menghasilkan keturunan yang baik dibandingkan dengan individu yang kurang cocok dengan lingkungan tinggal. Individu cocok dalam menghadapi geografis suatu daerah lambat laun akan mengakibatkan perbedaan yang signifikan pada pertumbuhan dan perkembangan dari fisik terlebih pada kepala dan wajah termasuk jaringan keras dan jaringan lunak sehingga lama kelamaan akan terlihat perbedaan dari walaupun tidak mencolok ${ }^{18}$. Generasi keturunan Arab Yaman yang dihasilkan selanjutnya secara bertahap akan menjadi suatu populasi yang sesuai dengan lingkungan hidupnya dan akan berakumulasi sepanjang generasi. Kemampuan setiap individu untuk bertahan hidup dan bereproduksi yang tidak sama ini akan mengakibatkan suatu perubahan secara bertahap dalam suatu populasi dan sifat-sifat menguntungkan akan berakumulasi sepanjang generasi. Kemudian lambat laun akan menghasilkan suatu modifikasi fisik yang berbeda dari dari keturunan asal ${ }^{19}$.

Faktor lingkungan lain yang mempengaruhi adalah nutrisi. Nutrisi sangat dibutuhkan pada saat tumbuh kembang pada saat sebelum lahir maupun setelah lahir. Nutrisi sendiri sangat dibutuhkan untuk pertumbuhan dan perkembangan tulang dan gigi geligi. Asupan makanan pada masa tumbuh kembang juga memegang peran sangat penting karena kelebihan maupun kekurangan asupan makanan dapat mempengaruhi pertumbuhan dan perkembangan ${ }^{20}$. Orang Arab Yaman yang tinggal di Indonesia selalu makan makanan yang berkarateristik Indonesia sehingga nutrisi yang dihasilkan sama dengan orang Indonesia. Karateristik geografi dan kebudayaan termasuk budaya makan juga mempengaruhi karakteristik 
morfologi gigi suatu ras ${ }^{21}$. Orang Arab Yaman di Indonesia mengalami perubahan ukuran gigi yang mendekati ukuran gigi orang Indonesia yang berasal dari ras Deutro Melayu. Hal ini diperkuat dengan penelitian pada populasi Amerika di Amerika, Jepang dan China diperoleh orang Amerika yang lahir di negaranya dibandingkan dengan yang lahir di Jepang dan Cina mempunyai ukuran mesiodistal gigi yang berbeda 22 .

Perbedaan hasil perhitungan antara rahang atas dan rahang bawah sesuai dengan penelitian Santoro et al (2000) Ditemukan tingkat variasi yang tinggi pada gigi geligi rahang atas dibanding gigi geligi rahang bawah. Hal tersebut juga dapat menjelaskan mengapa pada pengukuran rahang atas dan rahang bawah memiliki hasil yang berbeda dari masing-masing metode prediksi ${ }^{22}$.

\section{Simpulan dan Saran}

Tabel prediksi Moyers sesuai untuk memprediksi lebar mesiodistal gigi permanen pengganti rahang atas sedangkan tabel prediksi Sitepu sesuai untuk memprediksi lebar mesiodistal gigi permanen pengganti rahang bawah pada etnis Arab Yaman.

Perlu adanya penelitian lebih lanjut menggunakan metode prediksi lain untuk etnis Arab Yaman, perlu adanya penelitian lebih lanjut dengan jumlah sampel yang lebih banyak, dan perlu adanya penelitian lebih lanjut dengan menggunakan etnis Arab lainnya di Indonesia selain etnis Arab Yaman.

\section{Daftar Pustaka}

[1]. Buwembo, William. 2004. Moyer's Method of Mixed Dentition Analysis: a Metaanalysis. African Health Sciences Vol 4(1):4.

[2]. Kim, Fallahrastegar, Hur, Jung, Kim \& Lee. 2005. "Difference in Root Canal Length Between Asians and Caucasian". International Endodontic Journal. Vol. 38(3):149-151.

[3]. Lukman, D. 2006. Buku Ajar IImu Kedokteran Forensik. Edisi Kedua. Jakarta: CV. Sagung Seto.

[4]. Borzabadi-Farahani A, Borzabadi-Farahani A, Eslamipuor F. 2009.Malocclusion and occlusal traits in an urban Iranian population: an epidemiological study of 11 - to 14-year-old children. Eur J Orthod; 31:477-84.

[5]. Perillo L, Masucci C, Ferro F, Apicella D, Baccetti T. 2010. ;Prevalence of orthodontic treatment need in southern Italian schoolchildren. Eur J Orthod 32: 46-53.

[6]. Lysel L, Myrberg N. 1982. Mesiodistal tooth size indeciduous and permanent dentition. Eur JOrthod; 4(2): 113-22.

[7]. Moyers, E.M. 1988. Hand Book of Orthodontics. Year Book Medical Publisher. Chicago. London

[8]. Sitepu AN. Rumus kerja untuk meramalkan lebar mesiodistal gigi kaninus dan premolar yang belum tumbuh pada fase geligi pergantian.Tesis. Surabaya: Pasca Sarjana Universitas Airlangga;1983.p. 25-40..

[9]. Wiyono, J.K. 2016. Perbedaan Hasil Penghitungan Tempat yang Dibutuhkan dengan Metode Prediksi Sitepu, Nourallah dan Pengukuran Langsung.Journal of Dental Technology Vol. 5 No. 1 JanuaryJune 2016: 1 - 6 .

[10]. Bhatnagar A, Jindal MK and Khan SY. 2017. Applicability of Moyer's Mixed Dentition Analysis. J Dent \& Oral Disord. Vol; 3(4): 1069.Van Den Berg, L.W.G. 2010. Hadramaut dan Koloni Arab di Nusantara. Jakarta: Komunitas Bambu.

[11]. Huang SY, Kang T, Liu DY, Duan YZ, Shao JL. 2012. Variability in permanent tooth size of three ancient populations in Xi'an, northern China. Archived of Oral Biology; 57 (11): 1467- 73.

[12]. Brook AH, Griffin RC, Townsend G, Levisianos Y, Russell J, Smith RN. 2009. Variability and patterning in permanent tooth size of four human ethnic groups. Archives of Oral Biology; 54(Suppl.1):S7985.

[13]. Townsend $G$, Bockmann $M$, Hughes $T$, Brook A. 2012. Genetic, environmental and epigenetic influences on variation in human tooth number, size and shape.Odontology ; 100:1-9.

[14]. Sulastry. 2007. "Kolerasi antara Lebar Mesiodistal Gigi dengan Kecembungan Profil Jaringan Lunak Wajah Orang Bugis-Makasar". Dentofasial :Jurnal Kedokteran Gigi. Vol.6 (2): 73

[15]. Bisri, Affandi . 1999. Syeikh Ahmad Syurkati (1874-1943) Pembaharu dan 
Pemurni Islam di Indonesia. Jakarta: Pustakan al-Kaustar.

[16]. Mahmud, Amir. 2016. Adaptasi Sebagai Strategi Bertahan Hidup Manusia. ArRisalah; Vol. XVII No. 1.

[17]. Campbell. 2003. Biologi, Edisi Kelima-Jilid 2. Jakarta: Erlangga.

[18]. Koesoemahardja, H. D. 1993. Pola Pertumbuhan Jaringan Lunak Kraniofasial Serta Kaintannya Dengan Pola Pertumbuhan Jaringan Keras Kraniofasial Dan Pertumbuhan Umum. Majalah Orthodonti Indonesia

[19]. Yunus, Rosman, dkk. 2006. Teori Darwin dalam Pandangan Sains dan Islam. Jakarta: Prestasi.

[20]. Prijatmoko, Dwi. 2007. Indeks Massa Tubuh dan Konsumsi Nutrisi Pada Populasi Autis Yang Mendapat Pendidikan Di Sekolah Khusus Penyandang Autis. Indonesian Jurnal of Dentistry. Vol. 14(2): 132-135.

[21]. Arrieta, R., Yuniastuti, M., \& Leepel, L. A. 2003. Rahang dan Gigi Sebagai Sarana Identifikasi Forensik Untuk Menentukan Ras, Umur, dan Jenis Kelamin.IJD.ISSN 1693-9697. Vol. 13 (2) : 99-102

[22]. Dewanto, H. 1993. Aspek-Aspek Epidemiologi Maloklusi. Yogyakarta: Gadjah Mada University Press.

[23]. Santoro M, Ayoub ME, Pardi VA, Cangialosi TJ. 2000. Mesiodistal crown dimensions and tooth size discrepancy of the permanent dentition of Dominican Americans. Angle Orthod; 70(4): 303-7. 